UDC: $811.111^{\prime} 22$

\title{
THE TEXTUAL ISSUES OF MEANING-MAKING IN THEATRE AND FILM: A SEMIOTIC INTRODUCTION Peeter Torop (University of Tartu, Estonia)
}

In the semiotics of culture, text is a complex notion. Text as a whole emerges at the touchpoint of inner- and extratextual relations. Thus, text is a ternary whole made of signs (e.g., language is the 'material' for literature), specifically used (due to its artistic structure), and constructed in a certain cultural-historical context (including the author's worldview, their life experience, etc.). As a result, textual meanings vary on the subtextual, textual, and functional levels depending on the semiotic resource ('word'), text, and work of art.

Scholars use a range of criteria to analyze the structure of the text as a hierarchical phenomenon. On the one hand, to interpret the text structure is to compare it with the structure of the sign system (a semiotic approach) and the structure of the work of art (a functional approach). On the other hand, the structure of the text can be analytically described as compositional (from the point of view of exposition, rising action, climax, falling action, resolution, etc.), architectonical (title, epigraph, prologue, chapters, epilogue etc), or narrative (plot, story). The poetics of text, or the conceptual artistic whole, comprises the next level of analysis. Poetics is based on textual and intertextual characteristics, and proceeds from the conceptual value of the structural features of text.

From the viewpoint of contemporary multimodal culture, the same text may exist in different discursive formats, especially on the web, thus becoming an interdiscursive phenomenon (cf. Wildfeuer, 2014). Long before the Internet era, the issues of disourse in text, and text in discourses were partly described by Bakhtin. Meaning-making and text mentality depend upon the medium. In different media, meanings of the same text diverge (a) due to a particular purpose- or target-oriented activity (resulting in crossmediality, which is characteristic of marketing, education, and so on); (b) motivated by the necessity of creating secondary texts (pictures, music, film and theater adaptations, translations, comic books, parodies, etc.) corresponding to transmediality. In both cases, text proves to be a result of convergence (cf. Pearson \& Smith, 2015; Jenkins, 2006); in collective memory, the image of text is stored as a mental whole.

Textual meanings, the structure, and poetics of text are its internal characteristics. The interdiscursivity of text may be either internal or external. Internal interdiscursivity, for example, is an upspring of the writers' own illustrations as a part of their text as in Vonnegut's Breakfast of Champions (1973). External interdiscursivity is a variation of the same text in different discourses for different target groups such as Homer's Iliad in prose for adults and in adaptations or simplifications for children. Eco concluded:

Neither story nor plot is a question of language. Both are structures that can be translated into another semiotic system, and in fact I can tell the same story of the "Odyssey", with the same plot, by means of a linguistic paraphrase, in English instead of Greek, through a film or a comic book. In other cases, I can tell the same story of the "Odyssey" even though I partially change the plot, for instance, by starting with the events that Ulysses (in Homer's 
poem) tells the Ph[ae]cians about only later. However, in the original "Odyssey" there is not only story and plot but also the level of the discourse, that is, the so-called textual linear manifestation, or the Greek words with which Homer tells the story (Eco, 2001, p. 30).

Trans- and crossmediality indicate variations of the same text in different media such as film adaptations, theater performances, comic books, scientific publications, and oral presentations of the same novel. Concerning the media, the main questions under analysis are how this multimodal text is preserved in cultural memory, and which of its meanings dominates. On this level, text is not just a message, but a process of perception (consumption); and meaning-making depends on the order in which text variants constructed through different communication channels (verbal, visual, audiovisual, auditory) are received. Figure 1 illustrates the levels of textual meaning.

\begin{tabular}{|c|c|c|c|c|}
\hline TEXT & $\begin{array}{l}\text { TEXTUAL } \\
\text { FEATURES }\end{array}$ & \multicolumn{2}{|c|}{ POETICS OF TEXT } & $\begin{array}{c}\text { INTER- } \\
\text { TEXTUALITY }\end{array}$ \\
\hline DISCOURSE & $\begin{array}{l}\text { DISCURSIVE } \\
\text { FEATURES }\end{array}$ & \multicolumn{2}{|c|}{$\begin{array}{c}\text { INTERDISCURSIVITY OF } \\
\text { TEXT }\end{array}$} & $\begin{array}{c}\text { INTER- } \\
\text { DISCURSIVITY }\end{array}$ \\
\hline MEDIA & $\begin{array}{c}\text { MEDIA } \\
\text { FEATURES }\end{array}$ & \multicolumn{2}{|c|}{$\begin{array}{l}\text { TRANS- AND CROSS- } \\
\text { MEDIALITY OF TEXT }\end{array}$} & $\begin{array}{c}\text { INTER- } \\
\text { MEDIALITY }\end{array}$ \\
\hline & & & & \\
\hline
\end{tabular}

Figure 1. Levels of textual meaning 
Cultural experience is directly related to how languages of culture are cultivated in a given society at a given historical period. The richness of languages of culture correlates with the richness of multimodality and culture self-descriptive processes. Cultural experience exists in a cultural environment. As Lotman claims,

Genetically speaking, culture is built upon two primary languages. One of these is the natural language used by humans in everyday communication. [...] The nature of the second primary language is not so obvious. What is under discussion is the structural model of space (Lotman, 1992, p. 142).

The above-mentioned structural model of space can be reconstructed on the basis of Bakhtin's notion of chronotope (cf. Torop, 2019). Every text is either a space or a hierarchy of spaces. Together with time, space constitutes a leading space-time synthetical parameter of cultural research, an integral part of chronotope. Introduced in Bakhtin's works, the chronotope enriches both textual and cultural studies. Today, chronotopical analysis acquires great importance in the recent intersemiotic analysis (cf. Keunen, 2010).

Within the text, the chronotopical approach distinguishes three levels:

- the topographical chronotope is related to the story, it is the reality (an event or a succession of events, etc.) depicted in the text;

- the psychological chronotope lies in (un)marked viewpoints of the characters;

- the metaphysical chronotope determines the conceptions of text through the interrelations between different chronotopical levels.

Since these levels are not related to the 'material' of text, chronotopical analysis is particularly rewarding in comparing texts of different semiotic systems.

For a deeper understanding of poetics and artistic thinking of the author, it is important to treat text not only as an organised space, but also as a system of realities, or worlds, which it contains. In Bakhtin's parlance, the viewpoint is understood as chronotopical (it embraces space and time), emotional, and axiological (it comprises attitudes). On the assumption of the chronotopicality of thinking, Bakhtin worked out a methodological framework for chronotopical analysis, which provides a comprehensive understanding of the meaning-making mechanism in text. In this framework, the chronotope serves as a tool of holistic analysis for both text and culture since it specifies both characters' environment and author's horizon (Bakhtin, 2012, p. 506) in terms of 'the chronotope of a depicted event', 'the chronotope of the narrator', and 'the chronotope of the author' (Bakhtin, 2002, p. 393) cf. (Morson \& Emerson, 1990; Holquist, 1994).

Bakhtin also points out the role of the chronotope in the analysis of the extratextual aspect:

The work of art and the world represented in it enter the real world and enrich it; and the real world enters the work of art and its world as part of the process of its creation, as well as part of its subsequent life, in a continual renewing of the work of art through the creative perception of listeners and readers. Of course this process of exchange is itself chronotopic [...]. We might even speak of a special creative chronotope, inside which this exchange between the work of art and life occurs, and which constitutes the distinctive life of the work of art (Bakhtin, 1981, p. 254).

Within every text, there is an implicit or explicit coexistence of the 'word' and the 'picture', or of the narrative and performance. The basic semiotic binarity in defining the montage mechanisms lies in the discreteness and continuity on the level of language, textuality and processuality on the level of text, and narrativity and performativity on the level of semiosphere. On each chronotopical level, textual meanings differ due to the differences between the topographical storyworld as a reality; individual worlds, or subjectivity of the world perception by events participants; and the conceptual 
world, or authorial synthesis of all aspects of text. In figure 2 below, the unity of vertical and horizontal levels forms the sphere of semiotization (Figure 2).

\begin{tabular}{|c|c|c|c|c|}
\hline & & \multicolumn{2}{|c|}{$\begin{array}{c}\text { SPHERE OF } \\
\text { SEMIOTIZATION }\end{array}$} & \\
\hline LEVELS & \multicolumn{2}{|c|}{$\begin{array}{l}\text { NARRATIVITY } \\
\text { (semiotic resource) }\end{array}$} & \multicolumn{2}{|c|}{$\begin{array}{c}\text { PERFORMATIVITY } \\
\text { (picture) }\end{array}$} \\
\hline $\begin{array}{l}\text { TOPOGRAPHICAL } \\
\text { CHRONOTOPE }\end{array}$ & STORY & \multicolumn{2}{|c|}{$\begin{array}{l}\text { STORYWORLD, } \\
\text { INTERTEXTUALITY, } \\
\text { MODEL OF REALITY }\end{array}$} & EVENTS \\
\hline $\begin{array}{l}\text { PSYCHOLOGICAL } \\
\text { CHRONOTOPE }\end{array}$ & NARRATION & \multicolumn{2}{|c|}{$\begin{array}{l}\text { SELF AND OTHER, } \\
\text { INNERWORLDS, } \\
\text { MULTIMODALITY }\end{array}$} & $\begin{array}{l}\text { PERFORMING, } \\
\text { SHOWING }\end{array}$ \\
\hline $\begin{array}{l}\text { METAPHYSICAL } \\
\text { CHRONOTOPE }\end{array}$ & $\begin{array}{c}\text { VERBAL } \\
\text { DESCRIPTION }\end{array}$ & \multicolumn{2}{|c|}{$\begin{array}{l}\text { CONCEPTUAL WORLD, } \\
\text { PRINCIPLES OF } \\
\text { COHESION }\end{array}$} & $\begin{array}{l}\text { PICTORIAL } \\
\text { DEPICTION }\end{array}$ \\
\hline
\end{tabular}

Figure 2. Chronotopical levels of text and the sphere of semiotization

Semiotization (and semantization) suggests that, on the topographical level of chronotope, the storyworld is both the world of signs - things, names, situations, - and behaviors. On the psychological level, the innerworld is the world of semiotic states, thoughts, and words of personages. Finally, on the metaphysical level of the chronotope, the conceptual world is the world of the author's hypertheme.

Following Bakhtin's approach to 'creative chronotope' as an extratextual tool to analyze the readability of text in various situations, Lotman wrote:

...the sociocommunicative function of text becomes considerably more complicated. It may be reduced to the following processes: 1. Communication between the addresser and the addressee. The text functionsas a message from the information bearer to the audience. 2. Communication between the audience and the cultural tradition. The text functions as a collective cultural memory. In this capacity it reveals its potential of continual replenishment and retrieving certain aspects of the information stored in it as well as forgetting others, temporarily or totally. 3. The reader's auto-communication. It is especially important for traditional, ancient texts [...], playing the role of a mediator, helping to reorganize the personality of the reader and change its structural self-orientation and the extent of its links with metacultural constructions. 4. Communication of the reader with the text. Manifesting its intellectual properties, a highly organized text ceases to be merely a mediator in the act of communication. It becomes a full-fledged interlocutor, possessing a high degree of autonomy. 
For both the author (addresser) and the reader (addressee), it may serve as an independent intellectual structure, playing an active and independent role in the dialogue. In this respect, the ancient metaphor of "conversing with a book" turns out to be fraught with profound meaning. 5. Communication between text and its cultural context. In this case, the text is not an agent of a communicative act, but a full-fledged participant in it, as a source, or a receiver of information (Lotman, 1988, pp. 55-56).

Before Lotman, Jakobson transformed his own system of functions of language into a semiotic model of communication:

The question of presence and hierarchy of those basic functions, which we observe in language - fixation upon the referent, code, addresser, addressee, their contact or, finally, upon the message itself - must also be applied to the other semiotic systems. In particular, a comparative analysis of structures determined by a predominant fixation upon the message (artistic function) or, in other words, a parallel investigation of verbal, musical, pictorial, choreographic, theatrical, and filmic arts belongs to the most imperative and fruitful duties of the semiotic science (Jakobson, 1971, pp. 661-662).

In theories of literature, the semiotic model of communication is based on the ideas of theatricality or pictoriality of artistic texts and authorial styles. For Eisenstein, cinematographic montage was first used in literary texts (Tolstoy, Zola, and others). While this montage was understood mostly as narrative and temporal, Bakhtin's notion of chronotope suggested a new approach. At the beginning of the $21^{\text {st }}$ century, it was conceptualized by Manovich:

Twentieth-century film practice has elaborated complex techniques of montage with different images replacing each other in time, but the possibility of what can be called a spatial montage' of simultaneously coexisting images has not been explored systematically (Manovich, 2001, p. 323).

Complementarity is the core property of temporal, spatial, and chronotopical montage, as well as of narrative (on the level of story) and pictorial montage (on the level of a screen in case of film). At the same time, there are other possibilities for using chronotope in film studies (Alexander, 2007; Keunen, 2010).

For example, the 2012 British adaptation of Tolstoy's Anna Karenina is both a story and performance (cf. Hven, 2017; Pethö, 2010). The film has original artistic conditionality in describing the world of aristocracy (from space to body language). Contrary to this world is the world of the countryside and of manual work. Duality of these worlds forms a basic contrast on the level of topographic chronotope.

On the level of psychological chronotope, Anna, the protagonist, is described as a dynamic character in a static community. To show her loneliness in pursuit of love and meaning of life, the film uses Anna's movement between still images of people. On this level, there is a contrast between dynamic (Anna, Levin) and static personages.

The metaphysical chronotope, or the level of film conceptualization, represents the contrast and conflict between Anna and the society, urban and rural, artificial and genuine lives. Their dialogue yields a compromise; the influence of genuine life on artificial world is represented with a meadow on the stage in the final episode of the film. Different tools of artistic conditionality (stage, distorted proportions of things, artificial scenes, etc.) create this film conception. Figure 3 below illustrates the chronotopical structure of the film Anna Karenina. 


\begin{tabular}{|c|c|c|c|c|}
\hline & & \multicolumn{2}{|c|}{ 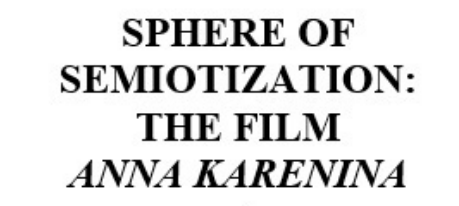 } & \\
\hline LEVELS & \multicolumn{2}{|c|}{$\begin{array}{l}\text { NARRATIVITY } \\
\text { (semiotic resource) }\end{array}$} & \multicolumn{2}{|c|}{$\begin{array}{l}\text { PERFORMATIVITY } \\
\text { (picture) }\end{array}$} \\
\hline $\begin{array}{l}\text { TOPOGRAPHICAL } \\
\text { CHRONOTOPE }\end{array}$ & STORY & \multicolumn{2}{|c|}{$\begin{array}{l}\text { WORLD OF SIGNS (THINGS, } \\
\text { NAMES, SITUATIONS, } \\
\text { BEHAVIOUR) } \\
\text { Historical costumes, } \\
\text { conditional theatrical } \\
\text { space, urban vs. rural life, } \\
\text { artificial proportions of } \\
\text { things }\end{array}$} & STAGE \\
\hline $\begin{array}{l}\text { PSYCHOLOGICAL } \\
\text { CHRONOTOPE }\end{array}$ & $\begin{array}{l}\text { CHARACTERS } \\
\text { OF NOVEL }\end{array}$ & \multicolumn{2}{|c|}{$\begin{array}{l}\text { WORLD OF SEMIOTIC STATES, } \\
\text { THOUGHTS, wORDS } \\
\text { Natural and artificial } \\
\text { behaviour, still images and } \\
\text { moving images as conflict }\end{array}$} & $\begin{array}{l}\text { DANCE-LIKE } \\
\text { MOVEMENT }\end{array}$ \\
\hline $\begin{array}{l}\text { METAPHYSICAL } \\
\text { CHRONOTOPE }\end{array}$ & $\begin{array}{l}\text { VERBAL } \\
\text { CONCEPTION } \\
\text { OF THE } \\
\text { NOVEL }\end{array}$ & \multicolumn{2}{|c|}{$\begin{array}{l}\text { WORLD OF HYPERTHEME } \\
\text { Dance as symbol of } \\
\text { artificial life, meadow on } \\
\text { the stage as compromise }\end{array}$} & $\begin{array}{l}\text { THEATRICAL } \\
\text { CONCEPTION } \\
\text { OF THE } \\
\text { NOVEL }\end{array}$ \\
\hline
\end{tabular}

Figure 3. Chronotopical structure of the film Anna Karenina

Semiotically, Anna Karenina (2012) is a filmic text, or a filmic adaptation of the literary text transformed into musical performance (by means of computer animation and spatial montage). From the point of view of 'material', it is a filmic adaptation, from the point of view of text, it is a transformation of a verbal story into a musical performance (using the 'stage' on the screen), and from the point of view of context, it is a modernistic work of art, an experimental interpretation of Tolstoy's classical novel. As a result, there is a difference between the three meanings: subtextual, textual and functional ones.

As Fischer-Lichte (2008) accentuated:

(A)n interplay of the semiotic and the performative dimensions has consequences for the processes of perception and meaning generation, which the spectators perform. To perceive the body, the things, and the space in their specific presence does not mean to perceive them as meaningless. Instead, all of these phenomena are perceived as something. We are not dealing with a non-specific stimulus here, mere sensorial data, but with a perception of something as something. [...] Their self-referentiality, accordingly, is not to be described as the mediation of a given meaning, or as a desemantization of a sign, but as a process of a very particular kind of production of meaning. This process is performed as the perception of 
a phenomenon in its particular materiality, in its phenomenal being. Perceiving and the generation of meaning, in this case, are performed in and by the very same act. Meaning is brought forth by and in the act of perceiving. In other words, in this case we do not perceive something first and then - in an act of interpretation - attribute the meaning of something else to it. Rather, the act of perceiving something as something is performed at the same time as the process of producing its meaning as this particular phenomenal being. I call this kind of perception the order of presence. From this, I distinguish quite another kind of perception and production of meaning, namely, the order of representation. To perceive the actor's physicality in its bodily being-in-the-world lays the foundation for the order of presence. To perceive it as a sign for a dramatic figure or another symbolic order establishes the order of representation (Fischer-Lichte, 2008, p. 77).

Analytically, it can be very productive to have some general tools for understanding meaningmaking on the elementary, denotational level in both theatre and film. Esslin suggests a tabulation':

Sign systems common to all dramatic media. 1. Framing systems outside the drama proper: $a$. Architectural framework and ambiance surrounding the performance; $b$. Title, generic description, pre-publicity; c. Prologue, title sequence, epilogue, etc. 2. Sign systems at the actor's disposal: $a$. Personality, balance of 'casting'; $b$. Delivery of the text; $c$. Facial expression; $d$. Gesture, body language; e. Movement in space; f. Make-up, hairstyle; g. Costume. 3. Visual sign systems: a. Basic spatial configuration; $b$. Visual representation of locale; c. Colour scheme; $d$. Properties; e. Lighting. 4. The text: a. Basic lexical, syntactic, referential meaning of the words; $b$. Style - high/low, prose/verse etc.; $c$. Individualization of characters; $d$. Overall structure - rhythm - timing; e. Text as action - subtext. 5. Aural sign systems: a. Music; b. Non-musical sounds.

Sign Systems confined to Cinema and Television.1. Sign systems derived from camera work: a. Static shots: long-shot, medium and full-close-up; b. Panning shots; $c$. Travelling shots; d. Slow motion, and accelerated motion shots. 2. Sign systems derived from the linking of shots: $a$. Dissolve; $b$. Crossfade; $c$. Split screen; $d$. Sharp cut. 3. The sign system of editing: a. Montage; $b$. Use of the rhythmic flow of images (Esslin, 1987, p. 103-105).

Esslin concludes: "Once the actual, factual, denotational level has been established, other levels of meaning intervene" (Esslin, 1987, p. 105) (italics in the original - P. T.).

Understanding higher levels of meaning-making is possible in the context of text (literary, filmic, or theatrical). Textuality, intertextuality, interdiscursivity, and intermediality emphasize the intersemiotic nature of meaning-making, text generation, and reception, i.e., different semiotic resources simultaneously construct different textual meanings. I argue, that an intersemiotic aspect of culture arises from a partial overlap of linguistic signs and sign systems of various arts on three text levels. First, it takes place on the level of independent existence of sign systems and texts created in them (e.g., film and theatre). Second, the whole text exists on the level of mental inference as an array of simultaneous texts (e.g., novel, film, performance, picture). Third, the semiotic overlap takes place on the level of projection to the propositional textual / intertextual background.

For an intersemiotic description of culture, both the recognizability of signs and the individual reception of texts is of great importance. In the intersemiosis of culture, sense-making and signs hierarchization does not solely depend on texts, since the same signs can belong to different texts or sign systems, and produce different meanings in different systems (Torop, 2000). Rather, the mechanisms of cultural perception are a basis for the explication of intertextuality, interdiscursivity, intermediality, and cross-linguistic issues; thus intersemiosis determines the semiotic ontology of texts of different cultures. 


\section{REFERENCES}

Alexander, L. (2007). Storytelling in Time and Space: Studies in the Chronotope and Narrative Logic on Screen. Journal of Narrative Theory, 37(1), 27-64.

Bakhtin, M. (1981). Forms of time and of the chronotope in the novel. In M. Holquist (Ed.) The Dialogic Imagination. Four Essays by M. M. Bakhtin (Emerson, C., \& Holquist, M. Trans.) (pp. 84-258). Austin, TX: University of Texas Press.

Bakhtin, M.(2002). Rabochie zapisi 1960 - nachala 1970 godov [Notes from 1960s - beginning 1970s]. In M. Bakhtin.Sobranie sochinenii v 7 tomah [Collected works in 7 volumes]. (Vol. 6) (pp. 371-439). Moscow: Russkie slovari, Jazyki slavjanskoi kultury,.

Bakhtin, M.(2012). Razroznennye listy k «Formam vremeni i hronotopa...» [Scattered sheets to "Forms of time and of the chronotope"]. In M. Bakhtin. Sobranie sochinenii $v 7$ tomah (Collected works in 7 volumes).(Vol.3) (pp. 504-511). Moscow: Jazyki slavjanskih kultur.

Eco, U.(2001). Experiences in Translation (A. McEwen Transl.). Toronto-Buffalo-London: University of Toronto Press.

Esslin, M. (1987). The Field of Drama: How the Signs of Drama Create Meaning on Stage and Screen. London, Auckland, Melbourne, Singapore, Toronto: Methuen Drama.

Fischer-Lichte, E. (2008). Semiotic and Performative Dimensions of Theatre. Journal of Dramatic Theory and Criticism, 22(2), 69-81.

Holquist, M.(1994). Dialogism: Bakhtin and His World. London: Routledge.

Hven, S.(2017). Cinema and Narrative Complexity: Embodying the Fabula. Amsterdam: Amsterdam University Press.

Jakobson, R. (1971). Linguistics in Relation to Other Sciences. In R.Jakobson. Selected Writings. (Vol 2). Word and Language (pp. 655-695). The Hague, Paris: Mouton.

Jenkins, H. (2006). Convergence Culture. Where Old and New Media Collide. New York, London: New York university Press.

Keunen, B. (2010). The Chronotopic Imagination in Literature and Film: Bakhtin, Bergson and Deleuze on Forms of Time. In N. Bemong, P. Borghart, M. De Dobbeleer, K. Demoen, K. De Temmerman \& B. Keunen (Eds.). Bakhtin's Theory of the Literary Chronotope: Reflections, Applications, Perspectives (pp.35-55). Gent: Academia Press.

Lotman, J. (1988). The semiotics of culture and the concept of a text. Soviet Psychology, 26(3), $52-58$.

Lotman, J. (1992). Text i poliglotizm kultury [Text and cultural polyglotism]. In J. Lotman. Izbrannye statji. (Vol .I). Statji po tipologii kultury (pp. 142-147). Tallinn: Aleksandra.

Manovich, L.(2001). The Language of New Media. London, Cambridge: The MIT Press.

Morson, G. S., \& Emerson, C. (1990). Mikhail Bakhtin: Creation of a Prosaics. Stanford: Stanford University Press.

Pearson, R., \& Smith, A. N. (2015). Storytelling in the Media Convergence Age: Exploring Screen Narratives. Basingstoke, New York: Palgrave Macmillan.

Pethö, Á. (2010). Intermediality in Film: A Historiography of Methodologies. Film and Media Studies, 2, 39-72.

Torop, P.(2000). Intersemiosis and intersemiotic translation. European Journal for Semiotic Studies, 12(1), 71-100.

Torop, P. (2019). Cultural languages and value of chronotopical analysis. In J. Haidar \& I. B. Ramos (Eds.). Fronteras semióticas de la emoción. Los procesos del sentido en las culturas. Libro homenaje a Desiderio Navarro (pp. 63-92). Mexico: ENAH, UNAM, 2018.

Wildfeuer, J. (2014). Film Discourse Interpretation: Towards a New Paradigm for Multimodal Film Analysis. New York, London: Routledge. 
Peeter Torop - Dr Sci., Full Professor, University of Tartu (Ülikooli 18, 50090 Tartu, Estonia); e-mail: peeter.torop@ut.ee; https://scholar.google.com/citations?hl=en\&user=78MfzbgAAAAJ

Пеетер Topon - доктор філол. наук, професор, Тартуський університет (вул. Улікоолі,18, Тарту, 50090, Естонія); e-mail: peeter.torop@ut.ee; https://scholar.google.com/citations?hl=en\&user=78MfzbgAAAAJ

Пеэтер Topon - доктор филол. наук, профессор, Тартусский университет (ул. Уликооли,18, Тарту, 50090, Эстония); e-mail:peeter.torop@ut.ee;

https://scholar.google.com/citations?hl=en\&user=78MfzbgAAAAJ 